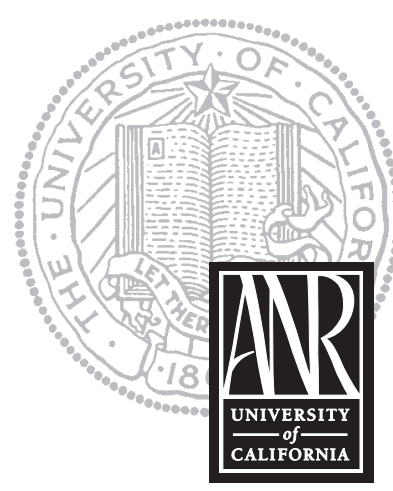

UNIVERSITY OF CALIFORNIA

Agriculture and Natural Resources

http://anrcatalog.ucdavis.edu

\title{
Fruit Trees: Planting and Care of Young Trees
}

JIM CARSON and GARY SHIMIZU, University of California Cooperative Extension Master Gardeners; CHUCK INGELS, University of California Cooperative Extension Farm Advisor, Environmental Horticulture, Sacramento County; PAMELA M. GEISEL, University of California Cooperative Extension Farm Advisor, Environmental Horticulture, Fresno County; CAROLYN L. UNRUH, University of California Cooperative Extension Fresno County staff writer.

\section{PLANTING}

Fruit trees should be planted where they will receive full sun for 6 or more hours per day during the growing season. For maximum production, fruit trees need soil that is deep (about 3 feet $[1 \mathrm{~m}]$ or more) and well drained. Such soils do not occur everywhere in California, especially in residential areas where the topsoil may have been partially removed by land grading and the remaining soil has been compacted by the weight of construction machinery. With proper irrigation management, however, fruit trees can be grown in as little as 1 to $1^{1} \frac{1}{2}$ feet $(30$ to $50 \mathrm{~cm}$ ) of good topsoil.

An additional complication in many areas is the presence of an impervious layer of hardpan or claypan beneath the soil surface. Where hardpan is found within $1^{1 / 2}$ to 2 feet (about 50 to $60 \mathrm{~cm}$ ) of the surface, it should be penetrated to allow for drainage and root growth. It may be possible to break through the hardpan with a pickaxe or by using a powered soil auger or jackhammer (available at equipment rental outlets). If there is no way to get through it, build a raised bed 1 to 2 feet (about 30 to $60 \mathrm{~cm}$ ) high and fill it with good quality soil. In any case, use care when irrigating to prevent saturating the soil in the root zone.

\section{Tree Selection}

Although fruit trees may be planted at any time of the year, they are often purchased during the winter months when they are dormant and available as "bare-root" stock. The best trees have a trunk diameter from $1 / 2$ to $5 / 8$ inch (12.5 to $16 \mathrm{~mm}$ ) and usually become established faster than smaller or larger planting stock. If bare-root trees cannot be planted soon after purchase, they should be temporarily "heeled in" by covering the roots with soil, sawdust, or compost, and keeping them moist to prevent drying out.

\section{Preparing the Planting Site}

If the soil is compacted, it must be cultivated deeply in a wide area because roots will not grow through densely compacted soil. It is best not to add soil amendments or fertilizers directly into the planting hole, although it may be beneficial to rototill well-decomposed compost into the soil around the tree before digging the hole. In heavy soils, undecomposed organic amendments may rot or be toxic to new roots. Wait until new growth is several inches long before applying fertilizer.

Dig the planting hole at least twice as wide as the spread of the tree's roots, but no deeper than the depth of the root ball unless the soil is deeply compacted. Leave the bottom of the hole undisturbed to help prevent the tree from settling below its root crown. This reduces the likelihood of crown rot, which often kills trees in poorly drained soil. In soil containing a high percentage of clay, score the sides of the planting hole with a shovel to aid root growth outward from the hole. 


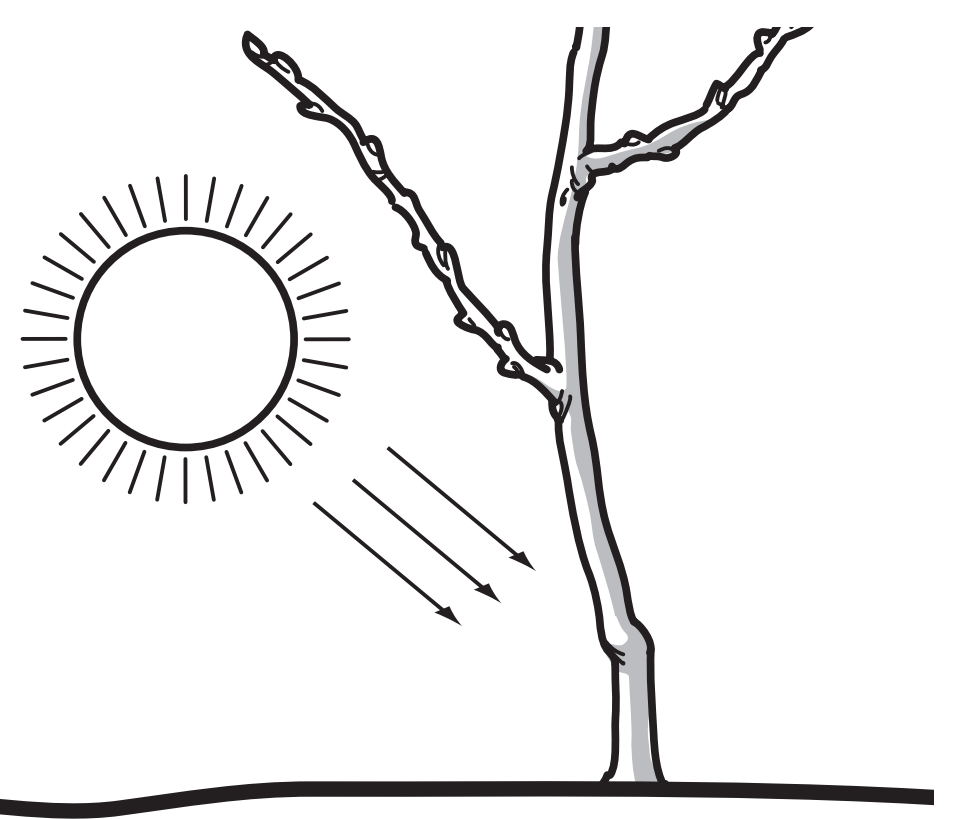

Figure 1. Direct the protruding notch of the graft union toward the northeast to protect the tree from sunburn.

\section{Planting the Tree}

Examine the roots of bare-root trees and cut off any roots that are broken or kinked. Container-grown trees may have circling or girdling roots, which should be gently pulled away from the root ball before the tree is planted. Place the tree in the hole with the graft union at least 2 to 4 inches ( 5 to $10 \mathrm{~cm}$ ) above the soil surface. The protruding notch of the union should be oriented toward the northeast to reduce the likelihood of sunburn (fig. 1).

Partially fill the hole with the same soil that was excavated and firm gently, eliminating large air pockets. When properly planted, the soil line on the trunk of the tree should be 1 to 2 inches ( 2.5 to $5 \mathrm{~cm}$ ) above the level of the surrounding ground. Placing a shovel handle or other straightedge across the hole can be a helpful way to check this during the filling process. As a general rule, after the soil has settled, the uppermost large root should be just below the soil surface. The soil should slope downward from the tree to prevent water from accumulating near the trunk. Once the tree is properly oriented, finish filling the hole and gently firm the soil into place.

\section{Irrigation}

All newly planted trees should be watered thoroughly to settle the soil around the root ball. If the soil is heavy loam or clay, care should be taken to avoid keeping the soil overly wet, since too much water eliminates air spaces in heavy soils, creating anaerobic conditions that can kill trees. For this reason, it is not always advisable to form a basin around the tree. However, trees should be basin-irrigated if the soil is sandy to loam, if the clay soil is dry, or if container-grown trees are planted during the growing season.

Construct a doughnut-shaped basin for watering the newly planted tree, making sure that water drains away from the trunk. The basin should be slightly wider than the planting hole so that water can be applied to the entire root area and just beyond. Most of the root volume occupies a rather limited area, particularly through the first growing season, so frequent watering may be needed until the roots become established. Fill the basin once or twice a week in hot weather, less often when it is cool or rainy. Water must soak into the root ball of container-grown trees since they cannot obtain water from the surrounding soil until their roots grow into it. Remove the basin in winter so that the tree does not stand in accumulated rainwater.

The ground within about 3 feet $(1 \mathrm{~m})$ of the tree trunk should be kept free of grass, weeds, or other vegetation that can compete with the tree for water and nutrients. A layer of mulch 3 to 6 inches $(7.5$ to $15 \mathrm{~cm}$ ) thick, such as wood chips, helps control weeds and conserve moisture. Mulch should be kept several inches away from the trunk to minimize the occurrence of crown rot and eliminate hiding places for insect pests. 

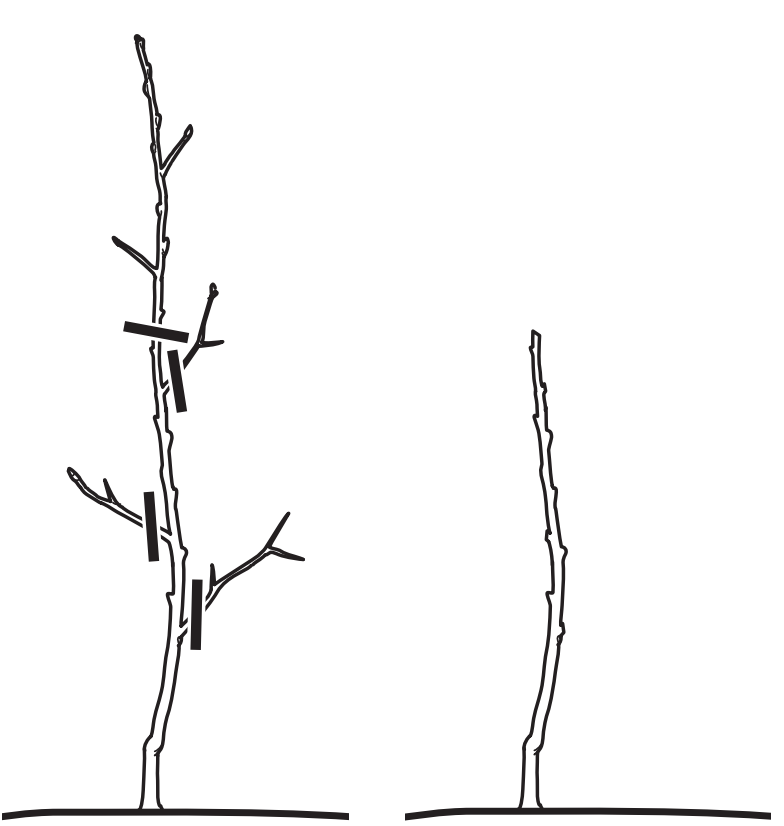

Figure 2. Remove all side branches, since small trees usually have no lateral branches on their trunks that are worth saving.

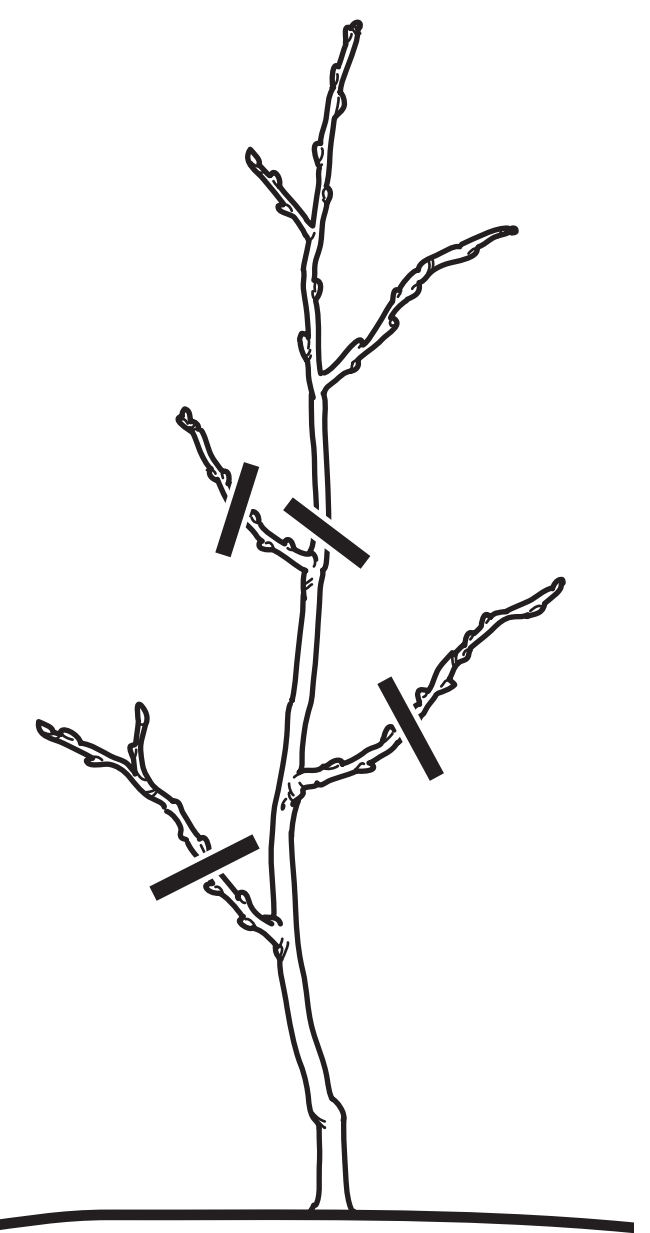

\section{Heading the Tree}

An important goal of backyard orchard culture is to maintain relatively small trees to facilitate pruning, thinning, pest management, and harvesting. By heading (cutting) the newly planted tree at knee height, about 18 to 24 inches (50 to $60 \mathrm{~cm}$ ), you force the tree to develop low branches. However, if access under the tree is important, head the tree higher, up to 36 inches $(90 \mathrm{~cm})$.

Small trees, those with a trunk diameter of $3 / 8$ inch $(9.5 \mathrm{~mm})$ or less, usually have no lateral branches on their trunks worth saving, so remove all side branches (fig. 2). Larger trees, $1 / 2$-inch (12.5-mm) diameter or larger, often have large lateral branches along their trunks. Some of these branches can be removed completely, but a few that are well spaced vertically and radially around the trunk can be headed back, leaving 3-inch $(7.5-\mathrm{cm})$ outward-growing stubs with two or three lateral buds (fig. 3). These stubs will produce shoots that will become the main scaffold branches.

\section{Sunburn Protection at Planting}

Protect the bark of the tree from sunburn and subsequent infestation by borer insects. For this purpose, use white interior latex paint diluted to half strength with water. Apply the paint mixture from 2 inches $(5 \mathrm{~cm}$ ) below the soil surface up the entire trunk, including the dormant buds.

Figure 3. Larger trees often have lateral branches that can be headed back, leaving stubs 3 inches $(7.5 \mathrm{~cm})$ long with two or three lateral buds. 


\section{CARE OF YOUNG TREES}

\section{Sunburn Protection}

Tree trunks may need to be painted again in the summer or in the second season if the canopy is not sufficient to protect the trunk from hot afternoon sun, especially on the south and west sides of the trunk. Any large branches exposed to several hours of afternoon sun should also be painted.

\section{Irrigation}

First-year trees do not require much additional water until the weather turns warm and new growth is several inches to 1 foot $(30 \mathrm{~cm})$ long. A healthy first-year tree with no mulch uses 5 to 10 gallons (19 to $38 \mathrm{l}$ ) of water per week in the summer, and much less than that where mulch is used. The frequency and amount of irrigation depends on the soil type, the method of irrigation, and ground cover, if any. For best growth, the soil in the root zone should be moist at all times yet well drained, although the soil surface may be dry. To determine if moisture is adequate, periodically dig down about 4 to 6 inches $(10$ to $15 \mathrm{~cm}$ ) with a shovel or trowel and examine the soil in the root zone.

\section{Training and Pruning}

It is important to prune young trees in summer to begin developing trees with the desired structure, rather than waiting until the dormant season. Dormant-season pruning is used to continue shaping the tree and to begin to manage young fruiting wood.

\section{FOR MORE INFORMATION}

You'll find more information on planting and care of fruit trees in the following ANR products:

California Master Gardener Handbook, Publication 3382, 2002.

Pests of the Garden and Small Farm, Publication 3332, 1998.

Pruning Fruit Trees, Video V85-A, 1985.

Training and Pruning Almond Trees/La guía y poda de los almendros, English and Spanish, Video V88-BR, 1988.

Training Young Fruit and Nut Trees, Video V85-B, 1985.

Training Young Trees for Structure and Form, Video V99-A, 1999.

Visit our online catalog at http://anrcatalog.ucdavis.edu.You can also place orders by mail, phone, or fax, or request a printed catalog of publications, slide sets, CDROMs, and videos from

University of California

Agriculture and Natural Resources

Communication Services

6701 San Pablo Avenue, 2nd Floor

Oakland, California 94608-1239

Telephone: (800) 994-8849 or (510) 642-2431, FAX: (510) 643-5470

E-mail inquiries: danrcs@ucdavis.edu 
An electronic version of this publication is available on the ANR Communication Services website at http://anrcatalog.ucdavis.edu.

\section{Publication 8048}

Funding for this publication was made possible through a grant from the Elvenia J. Slosson Fund.

(C) 2002 by the Regents of the University of California, Division of Agriculture and Natural Resources. All rights reserved.

The University of California prohibits discrimination against or harassment of any person employed by or seeking employment with the University on the basis of race, color, national origin, religion, sex, physical or mental disability, medical condition (cancer-related or genetic characteristics), ancestry, marital status, age, sexual orientation, citizenship, or status as a covered veteran (special disabled veteran, Vietnam-era veteran or any other veteran who served on active duty during a war or in a campaign or expedition for which a campaign badge has been authorized). University Policy is intended to be consistent with the provisions of applicable State and Federal laws.

Inquiries regarding the University's nondiscrimination policies may be directed to the Affirmative Action/Staff Personnel Services Director, University of California, Agriculture and Natural Resources, 300 Lakeside Drive, 6th Floor, Oakland, CA 94612-3550 (510) 987-0096. For a free catalog of other publications, call (800) 994-8849. For help downloading this publication, call (530) 754-5112.

pr-5/02-SB/WS

ISBN 978-1-60107-226-9

This publication has been anonymously peer reviewed for technical accuracy by University of California scientists and other qualified professionals. This review process was managed by the ANR Associate Editor for Environmental Horticulture. 